\title{
Assessing China's Soft Power Diplomacy in Africa in the Context of Postmodern Thinking
}

\author{
Sylvester Tabe Arrey \\ International Master in Peace, Conflict and Development Studies of the University of Jaume I (UJI), \\ Castellón, Spain. \\ UNESCO Chair of Philosophy for Peace \\ Tel +34 964729380 , \\ E-mail address: astarrey@yahoo.com, epd@uji.es
}

\begin{abstract}
Africa is progressively becoming an appealing continent to many of the supreme economies of the world. It is now evident that most of the world's super powers such as the US, Germany, United Kingdom, Russia, China and others have resolutely taken interest in the economic, political, health and social affairs of the continent. The continent's value in terms of resources and potentials has been highlighted as the major motivation behind this drive. This paper evaluates China's motives and activities on the continent of Africa and how this is likely to affect the world's economies. The article focuses on the approach China is using in Africa and how this approach can be viewed using postmodernism. It intends to stir the reasoning of the reader to venture into new trends of critical thinking and therefore, creates a platform that encourages one to dare to think deeper, wider and differently about certain aspects of current Sino-African relations. This paper gives insights into a deeper understanding of a number of things as the rising power called China is busy carrying out actions which do not only consolidate her position in the continent, but have also enabled her to outshine many of her predecessors on the continent.
\end{abstract}

Keywords: China; Africa; Postmodernism; Soft Power; poverty and development

\section{INTRODUCTION}

A couple of years ago, China was not quite a force to reckon with in Africa and few would even mention its name when talking of Africa's veritable partners and friends. The continent was like a reserved zone for some powers that came mostly from the northern hemisphere, notably the United States, France, Germany, Spain, Portugal and the United Kingdom who dominated in virtually every conceivable domain. These powers were fully in charge of many of the opportunities the continent offered and were its main partners both at bilateral and multilateral levels, taking the lead in trade, aid, diplomatic relations and investing heavily in oil, telecommunications and other major sectors that constitute the livewire of the economies of many African states. In fact, from an imbalanced relation between colonies and their owners, things quickly took a different trend, shifting from colonization to cooperation after the colonies broke loose from the noose of domination and became sovereign entities.

For the case of the United States, it was not as difficult settling to find friends in the continent during the new dawn as many probably anticipated. This was partly because it 
carefully presented a cajoling character during the days of colonisation, exposing the inadmissibility of certain experiences of the colonized lot and joining them in decrying colonialism's unfairness through bodies like the United Nations, arguing that in line with the principle of self-determination it was the right of the people to run their own affairs in a manner they deem best - arguments which significantly contributed in bolstering the momentum of the continent-wide independence struggle which became so strong like a raging hurricane against which the old order eventually capitulated. Even though the Cold War pushed the US to meddle in certain territories' affairs in a manner that stirred the ire of many and triggered alienation, its careful use of good behaviour and the image it brandished internationally as a kinder power and an advocate of liberty whose hands were clean in terms of keeping others in colonial bondage significantly made things up for it.

After eventually joining the global family of free nations, many of the former colonies thus had a fairly different perception of the US vis-à-vis some others. Therefore, unlike the former owners of colonies who spent considerable energy mending fences and attempting to heal bleeding psychological wounds to get a place in the good books of the new states, the United States spent its time building on the foundation its solidarity had established for it.

With the perception advantage, vast size, a powerful economy and an ever-rising power level, the US's growing position in Africa fairly threatened others who wasted no time carving out spheres of influence on notably historical and linguistic grounds such as FranceAfrique and La Francophonie for the case of the French, and The Commonwealth of Nations, for the case of the British, in order to prevent them from being booted out and playing second fiddle in territories they have invested a lot in and barely a while ago, were the undisputed lords and controllers of their fortunes.

However, it is worth highlighting the fact that because they were operating within the context of the Cold War, the threat of encroachment from the likes of the US was not as great as that posed by the likes of the Soviet Union. New arrivals like the US were to be guarded against and be allowed to get only as much as cannot be prevented but the likes of the Soviet Union were to be flatly stopped. Eventually, with disparities in trade and investment levels, the US and the other western powers became the regular partners and allies of the continent, deploying various techniques including inter alia, the introduction of diverse forms of aid and cooperation agreements ranging from the military to the economy to fortify their influence base and promote a sense of camaraderie to contain the communist threat from the Soviet Union and its peers.

It was a new dawn indeed and the roots of these powers grew so deep that they became the familiar names in many things relating to the continent's bilateral and multilateral transactions. In fact, long before, and notably after the disintegration of the Soviet Union, the western powers, as some will lump them and label, were firmly in command of things, dominating in virtually every domain in the continent.

Not anymore! This trend has been significantly altered and things have shifted, taking a completely different trajectory as China currently has a massive presence in Africa, investing in gas, oil, telecommunications and virtually every sector that is worth risking into. Unlike the United States and the other European predecessors who have been more or less coercive and put conditions such as good governance, free and faire elections, promotion of human rights and democracy for African governments to meet in exchange for economic and other opportunities, China avoids that approach. It gives what one wants and takes all it needs, not directly stepping in to keep track of how recipients treat their people or how they use what they receive. It argues that it does not mix business with politics and does not make political 
impositions or prescriptions to others when business is actually what is on the table (Bezlova, 2006, 1).

Its style irritates others and has triggered the questioning of its real intentions. Many foreign voices have been on its neck raising concerns about what they see as its off-the-rules approach but China is exhibiting a type of 'who cares' attitude and continues with all diligence with what it calls the 'Win-Win' [or Soft Power] diplomacy, trying to get Africa on its side an act which will certainly reinforce its global position and eventually permit it to sit unperturbed on the cockpit of world affairs as the world's new pathfinder. It does not take lightly the role the continent of Africa and its vast resources mean to anyone who dreams to assume a commanding position in the currently competitive and constantly mutating global system. It is, therefore, carefully presenting an attractive image of itself to lure Africa to its side. Despite mounting criticisms, the rising power looks unshaken, appearing focused and levelheaded, choosing instead to intensify its activities in the continent and considers the likes of the Council of Foreign Relations (CFR), the Congressional Research Service (CRS) and other such US and Europe-based bodies that have raised strong voices against it as 'superpower brain trusts' who are bent on preserving their governments' hegemonies in what to them is their sphere of influence and a no go zone to newcomers of its type (Sautman, 2006, 1).

This is pretty intriguing and is the driving force which instigated the research that birthed this chapter which focuses not only on China's soft power and its raison d'être in the resourceful continent at this particular time but how its activities can be assessed in the context of postmodernism, one of the prevailing discourses that influence policy orientations and international relations in many circles nowadays.

This chapter focuses on the approach China is using in Africa and how this approach can be viewed using postmodern lenses. In fact, the discourse of postmodernism has deconstructed many concepts previously held in high esteem and it has significantly modified and in some cases, changed the perception of many key concepts and thought patterns including the perception of aspects such as development, the notion of an absolute truth, underdevelopment, poverty, just to name these few, such that in an era like this, it is imperative to be sure of how adaptive and fitting the approaches and partners which state and non-state actors accept will eventually affect them and how beneficial such choices will be to the wider expectations of their people. The chapter equally intends to stir the reasoning of the reader to venture into new trends of critical thinking - creating a platform that encourages one to dare to think deeper, wider and differently about certain aspects of current Sino-African relations.

China, quite often, is a player that does not make much publicity of its deeds and as Deborah Brautigam highlights, its official information and statistics, especially those that seem sensitive could be really hard to come by (Brautigam, 2009, 3). Therefore, to understand this power and accurately track its course, people need to both be keen and cast their facts-collection net as wide as possible. That China has successfully positioned itself as a force to reckon with is no longer contestable but its soft power diplomacy in Africa and the real reasons behind it remain vague, controversial and still to be fully understood. This chapter has provided tips which can contribute in broadening current understanding of a number of things as the rising power is busy carrying out actions which do not only consolidate its position in the continent but have enabled it to outpace many of its predecessors in this new race which looks like another scramble for Africa.

The chapter equally pits arguments against some of the dominant arguments that have been made so far about China's activities in Africa, wrapping up with the part Africa can play in determining the future structure of world leadership. Here, the current value of the continent in terms of resources and potentials has been evoked, showing how this can power the running 
of the new economic engine that is poised to pull the world along. Africa will be crucial to this and China seems to be aware of it and is ensuring that its link with the continent is potent enough to sway the needed edge to its side.

\section{DEFINITION OF KEY CONCEPTS}

\section{1. Soft Power Diplomacy}

Following the way we have used it, there will be no better way of defining soft power but from the point of view of Joseph Nye, the man who coined the term and brought it to popular use in scholarly and professional circles. By soft power, we simply mean a synergy of actions and behaviours which work together to place one in a position of being able to obtain what one wants through co-option, attraction and acceptance rather than through the use of coercion, payment, or direct pressure (Nye, 2004, 10). It is power or influence which develops and becomes available for use by a state or any other actor as a result of its attractiveness, the charm of its culture, political ideals, policies and ways of doing things. When an actor's ways are pleasant, attractive, loved and considered to be legitimate by others, it tremendously bolsters its soft power and positions it to easily have its way and obtain results especially if it understands the dynamics of taking advantage of what it has to make a way to what it needs. We will be considering China's in Africa.

It is worth highlighting that profitable results are what states and their people need and they always prefer to have it in a manner that is less costly. Wars, threats, negotiations and other modes of states' behaviour are all geared toward obtaining results. Soft power has witnessed a rapid growth in recent times as a powerful means to an end which is not only less costly but is less bloody. It is premised on the realization that there are many ways of getting what one wants and that force, which has been mostly used in many instances, is neither the most rational nor the least costly. One's opponent or partner can deliberately and happily hand over what one desires, not because they were compelled to, but because they were moved by one's charming attitude and the attractiveness of one's policies. This is soft power at work. It is currently what China prefers using in Africa. To ensure success and continuity of its rapid growth and activities in the continent, it has put in place a well calculated soft power strategy and a set of cajoling tools to get the strategy successfully implemented in all its target areas (Kurlantzick, 2007, 11) in order to obtain a comfortable position and also not to be easily ejected from the scene by not only its powerful predecessors but other meaningful new comers and aspirants like India, South Korea, and Brazil.

\section{2. Postmodernism}

Even though the likes of Jean Baudrillard, Michel Foucault, Jean-François Lyotard and Gilles Deleuze remain among the major scholars of postmodern philosophy from whom much can always be drawn, we prefer to explain it, tapping not too much from them, but from the more condensed point of view of Steven Best and Douglas Kellner. It must be acknowledged that it can be challenging to ascribe a unique, one-phrase definition to this term because of its hybrid character that lumps many things into a single word. Nonetheless, postmodernism will be taken here as the discourse which succeeded modernism, characterized by a strong reaction against the assumed certainty of scientific or objective way to explain reality. In essence, it stems from recognition that reality is not static and limited to human understanding of it but is constructed as the mind tries to understand its own particular and personal reality. Hence, postmodernism is against explanations which claim to be final and valid for all groups and 
peoples and instead focuses on the relative truths of each individual (Best and Kellner, 1991, 4-5). As far as postmodernism is concerned, at least in the way it serves in this work, interpretation is what matters; reality only comes into being through people's interpretation of what a situation means to them personally. So, it stresses on relativism and context-based judgments which are free from the notion of an absolute, infallible truth that is sure and true for all.

\section{CHINA'S USE OF SOFT POWER AND THE RESPONSE OF OTHERS}

\section{1. Soft power in use}

China's current presence in Africa is massive and is not only limited to bilateral ties with governments but stretches down to the involvement of Chinese in everyday life including petit commerce. This sudden influx has the potential of triggering any form of resistance from not only governments who have the mandate to protect their people but from locals themselves who might not like to compete with such a large number of Chinese in their space. Conscious of this, China has embarked upon the use of Soft Power Diplomacy to make not only its government to be accepted, but its nationals as well. For example, it has chosen to act differently from the other powers that preceded it, giving Africa aid on seemingly generous terms and pursuing what it calls 'win-win' style of doing business with other states and peoples, constructing roads, hospitals, schools, pipe borne water and many of the things the continent previously stooped to imposed conditions of its western partners to get. In addition to other quiet, cajoling behaviours, China has succeeded in getting itself accepted in many circles in Africa, arguing that it is a different type of global power who respects the continent's diversity and being a developing country itself, it understands Africa's development challenges and stands a better chance of advocating for it in international trade negotiations and other fora where others have chosen to take advantage of its recipient position to prescribe austerity conditions which must be respected in order to qualify for assistance and other available opportunities (Kurlantzick et al., 2006, 1).

This should not be taken to mean that soft power is a Chinese thing. It has been in existence for long but actors go for it only depending on how useful and productive they think it is in a given circumstance or political season. By 2008 for instance, even though the talk of China and soft power was already very widespread and it seemed as though it was a new Chinese property, a study conducted around then revealed that though China's use of soft power was truly on the rise, it still lagged behind powers like the United States whose use of soft power was greater in a number of places around the world including Asia (Mingjiang, 2009, 2). In Africa, however, China's use of it was on a sharp rise, producing plausible results.

According to Michel and Michel, China is having its way and has been so successful that bilateral trade between the rising power and Africa multiplied 50 fold from 1980 to 2005 and it quintupled between 2000 and 2006 from $\$ 10$ billion to $\$ 55$ billion and approached $\$ 100$ billion in 2010; and it has overtaken France as Africa's second largest business partner and was predicted to catch up with the US on first position and even eventually overtake it if its rate of progress remains consistent (Michel and Michel, 2009, 3).

Nonetheless, from the perspective of postmodernism where nothing is absolutely true, the flashy activities of the Chinese and their seemingly good and 'win-win' acts of philanthropy must be keenly watched because as John Rourke puts it, international relations is never a manifestation of true friendship where true love for others exists in earnest; it is merely an interest-driven relations where one's eyes are fixed on what one aims to get, using any means 
and any tactic; even the one of being the first to give (Rourke, 1991). Moreover, as Ian Taylor indicates, China has a strong interest on Africa's oil and other resources to power its fastgrowing economy and a look at its top ten trading partners in Africa around 2004 for instance, when the soft power talk was spreading so wide, revealed that they were the leading oil producers of the continent (Taylor, 2007, 3).

This is not to undermine China's sense of goodwill but is simply to highlight that in the context of postmodernism, which is the ground on which this chapter is built, both the defendants of China's activities and its critics (few of whom we shall see below) can be right just as they can be wrong since there is no universally acceptable devise for measuring the real nature of such activities to determine what they truly represent. Moreover, such judgments should be relative and should depend on the interpretation of the concerned parties in their own context because from a postmodern perspective, the meaning of a thing depends on the interpretation the concerned parties give to it, taking into account their own context and peculiarities.

Consequently, going by postmodernism, it could be considered as exaggerated boldness and perhaps overconfidence, passing a verdict that sounds final on what China's activities mean to Africa and how Africa must respond to it. Some of the judgments passed so far, truly speaking, appear really conclusive in the way they explain China's raison d'être in the continent. The examples given here are not to discredit in any way the good job and enormous sacrifice of the concerned but are intended to serve as a sample to bring clarity to the message this section seeks to get across; without which some comprehension issues might linger on.

Deborah Brautigam for instance, in her fascinating and insightful book, The Dragon's Gift: The Real Story of China in Africa, which is full of evidences to back up her arguments, questions the sincerity and truthfulness of China's 'gifts' to Africa indicating that after spending her childhood in Africa and going back there as an adult to research on the activities of the Chinese, she found the gifts of the Asian giant to Africa to be nothing but gifts from a dragon which traps the recipient in an unending cycle of dependence and underdevelopment, (Brautigam, 2009). Robert Rotberg for his part insinuates that if they fully succeed, China's activities will make Africa the poorest and most troubled continent in the world in the nearest future (Rotberg, 2008, 13). There are many others that conclude in similar lines.

Does it mean that after spending time carrying out lengthy, laborious research, the ideas of these researchers do not deserve their place? Of course they do. The researchers did a great job but just as they might be right, so too might they be wrong because going by the context currently under study, everything always remains open and no one can conclude with a full stop and claim that that is where it ends and that is the message to be taken home.

Now, if what the Chinese say in defence of themselves are not true and the accusations leveled against them by critics are not true either, what then is true and who is correct, given the fact that at least one side of the coin should be up no matter how it is cast? Well, that is according to normal thinking based on common logic, not with postmodern thinking. With the latter, everything always remains open and what is right or wrong only depends on the way one sees it in that context and at that time as it relates to them. Thus, China-Africa relations can mean anything; but the meaning that will prevail is, evidently, not the one postulated by any seasoned scholar with a refined mind but the one the two parties themselves give to it which will eventually determine whether the relationship is worth continuing or should be terminated.

\section{2. The response of others}

As China gets busy with its soft power diplomacy, many have come out expressing concerns which, as we shall see, sound good but worrisome and controversial within the context 
of postmodernism. In 2006 for instance, the US Council on Foreign Relations (CFR) complained against China's attitude in Africa accusing it of supporting 'rogue regimes' in the continent and making diplomatic compromises which only serve its economic needs but undermine the efforts of other donors who are striving to make recipient governments responsible and accountable (Sautman, 2006, 1). But again, China argues that its hands are clean and it does not mix business with politics. In what appears like a response to this kind of talk, the $B B C$ News of Thursday 1 February, 2007 indicated that there is no such thing as a politics-free oil contract. Moreover, Diana Choyleva, a Senior Economist at Lombard Street Research in London indicated that though it is true that China's aid comes with no conditions and aid from its predecessors is full of conditions, the worrisome issue about the Chinese approach revolves around the issue of whether any effort is made to ensure that revenue from the resources of the countries they deal with actually benefit the countries or just ends up wherever. This, of course, is an observation that truly reflects much of the way China operates and the things that transpire on the ground.

For their part, Human Rights Watch and Amnesty International have raised concerns severally against the Chinese government of endangering human rights in some of the places in which they operate. British news paper, The Guardian, of Sunday February 6, 2011 carried as one of its stories, the issue of China-Africa relations which it captioned "China's Economic Invasion of Africa," a language which reflects very much the view of a significant quota of British political cadres, foreign policy personnel and loyalists regarding the presence of China in Africa.

In the same trend, Adama Gaye describes China-Africa relations as that between a dragon and an ostrich with the dragon so big and really dreadful (Gaye, 2006). From the photograph of a gigantic dragon perching on a helpless ostrich that the cover of his book carries, his position is clear and carefully argued with various evidences weaved into a convincing whole. The list of critics is long and many argue that China is backing African dictators and this is not good for the poor masses who ought to be the target group of all development and cooperation schemes in order to make their living conditions better.

Despite the fact that these views have been put forward by professionals and experts who must have keenly studied the situation before commenting, it does not mean that they are automatically right neither does this statement imply that they are wrong. Again, it depends on who is judging and the context of such judgment. China, for instance, might truly be an ally of regimes considered to be dictatorial but it will be naïve for anyone to think that its predecessors do not deal with dictators and they truly care for the poor and have strict people-oriented conditions which, if not respected, they will have nothing to do with any oppressive leader or regime as is purported. They, no doubt, want to see good governance, democracy and a peoplecentred government in countries but they will press forth for these only up to the point where their own interests are healthy and alive. In fact, states are not philanthropic organizations with a true sense of charity - they rarely engage in activities that diminish them and cause them to incur deficits. So, authors of academic and professional works might be right to describe China as a dragon given the intensity of what they surely discovered while researching in the field but to conclude that it is not a good relationship and it will make Africa poorer if it goes on, is, from a postmodern standpoint, worrisome and perhaps a manifestation of intellectual arrogance and pomposity.

In this context, it is not up to anyone to make a definitive conclusion and prescribe how others must view it because their meaning and judgment of good relationship, development and poverty, for instance might not be the same with what their readers or the Chinese and Africans consider good relationship and poverty to be. Besides, it is possible that other research 
initiatives on the same subject can produce contrary results. Things of this nature are contextbased and at times, socially constructed, leaving only those directly concerned with the legitimacy to bring out their own meaning in a way that suits them and permits them to satisfactorily relate to circumstances as they will want to be affected by them (Esteva, 2006, 83-84).

In a different but related line of reasoning, the likes of Nicholas Georgescu-Roegen, Serge Latouche and Joan Martínez-Alier hold that the issue is not too much about who is in charge as it is about the system that is being used. They hold that it does not matter who is in charge or whether states deal with others in good or bad faith; what matters is that as long as they are operating in the current growth-oriented, neo-liberal economic model characterized by intense competition in a survival-of-the-fittest environment, there will always be exploitation and rogue behaviours not necessarily because particular state actors have bad manners but because the system itself promotes greed and exploitation and is directly responsible for the behaviour of both states and people against one another (Martínez-Alier et al, 2010, 1741). They hold that it is time to have an alternative economic model which they have chosen to call de-growth. This model advocates for a society which is not in a desperate rush to grow and will do everything to achieve it. It lays emphasis on simplicity rather than complexity, cooperation rather than competition, sharing rather than selfishness, insisting on a greater use of real economy in which the value of natural and human capital are recognised unlike the current paper economy where money is deified and everyone who does not have it, be they talented or skilful, are relegated to the backside of society where they suffer excruciating poverty and lack (Gomes, 2012, 2-3 and Martínez-Alier et al. 2010, 1741).

Advocates of this model argue that wealth, development and good life is not necessarily having much money, skyscrapers, many cars and a big house near a natural feature like the beach. Being truly happy, unlimited, and able to make the most out of life are the essence of life itself and attaining these, requires a vision that incorporates certain other hard realities. One of the ways this can be attained is through an alternative path which is different from what many of them see as the unsustainable, susceptible-to-exploitation and competition-pruned neoliberal model which advocates for continuous economic growth and greater integration of the market. As indicated already, this alternative path focuses more on the wellbeing of the entire members of the society as a collective whole and not the dominance of a powerful few in a system that promotes and reproduces inequality, poverty, unsustainability and violence. It stresses on cooperation, simplicity, interconnectedness and an indigenous sense of collective responsibility and selflessness.

Despite raising fascinating arguments and making inspiring insights which have had significant positive impact on scholarly and professional milieu regarding why an alternative that makes up for the flaws of the currently dominant system is necessary in challenging times like this, Alberto Gomes, though in agreement with much of the concerns of the de-growth theorists, notes that they failed to map out a clear path that leads to what they have proposed and in an attempt to contribute in filling this gap, presents a 'holistic model of an indigenous social ecology which represents a radical shift from the growth-fetish economism of mainstream development to an ecological imagination that can bring about real sustainability' (Gomes, 2012, 2).

He highlights that:

Particular aspects of indigenous social life are of immense epistemological value for rethinking and reformulating development policies and economic models from one that negatively impacts on humanity and nature to one that can lead to a better 
life for all. Such policies and models would obviously need to be appropriately modified or adapted to suit the social scale and population size and density of 'modern' social life (Gomes, 2012, 3).

Going by this trend of reasoning and given the fact that many African nations are made up of societies with a strong sense of fraternity and community life, much in this model make a great deal of sense and taking it seriously might be wiser than just castigating it as a utopian rhetoric and an unrealistic idealist thought that does not connect with the realities of the current complex and fast-moving hi-tech world. As Kofi Busia indicates about certain West African communities before modernism came in full force, the level of interconnectedness, cooperation and shared responsibilities was so real that in many communities for instance, when a wife prepares food, the husband seldom eats alone but sends for his brother or neighbour and the eating was done together in a cooperative, happy manner as they joyfully discussed issues of general interest, spending their time in happiness and in an ecologically friendly manner (Busia, 1968).

If this is originally the modus vivendi of the people and the foundation on which their mode of life is built, the arrival of China and its careful use of soft power will make a significant positive impact only if it pays keen attention to much of the people's uniqueness and the peculiarity of the foundation carrying them. Building on this foundation with full recognition of these will tremendously make a difference, if not, despite any hysteria that might accompany the new Chinese arrival, it is just a matter of time and the same concerns and worries will spring back - proving that they actually went nowhere but were simply covered up by new happenings.

This statement is premised on the idea that the issue is not really about China as an actor but about the economic model it is using or operating in. Going by the current growth-centric, neo-liberal system, anyone in their shoes, no matter how good and noble their intentions might be, will not perform very differently and that is why their 'western' predecessors were accused of exploitation and many other things, they are currently being accused of exploitation and many other things and their successors will likely be accused of exploitation and lots more, everything being equal.

Africa, though, has its destiny in its hands and therefore has a major role to play in the midst of these interactions to determine how to have the expectations of its masses met and not just change partners regularly. Moreover, with its potentials and abundant resources, it has what it takes not only to influence the behaviour of certain leading powers but can effectively have its say in world affairs and determine who takes the lead if it cannot do so itself.

\section{AFRICA'S POTENTIAL ABILITY TO INFLUENCE THE STRUCTURE OF FUTURE WORLD LEADERSHIP IN THE POSTMODERN SETTING}

\section{1. Power of natural wealth}

This section is not intended to make any exhaustive analysis of the total endowment of the continent. What is worth noting, however, is the fact that it is the bedrock of multiple resources and divers wealth which are currently supporting and are equally needed by different economies and major businesses around the world. According to Zartman and Rubin, there are a handful of sources from which states' ability to influence others come from - their power, so to speak. These things place them in a position to wield tremendous influence over others, especially if they master how to deploy them in a potent manner when results are needed. These sources include, inter alia, the size and population of a territory, the type and quantity of natural 
wealth a territory possesses, technological advancement, the type and number of friends a territory has, soft power, and military power. If any of these or a combination of them, is at the disposal of any political entity, it will directly place at its disposal enormous power which is taken here to mean the ability to get results. In other words, it is what gives one party the capability to have its way or move another party in a desired direction during negotiation or any other form of interstate business (Zartman and Rubin, 2000, 7).

With the exception of technological advancement, the continent is well endowed with much of the rest - it is well positioned to have a voice that is not only sought after but cannot also be easily ignored. Being quite vast with a land area that exceeds 30 million Km square including a number of islands and archipelagos, it is the second largest continent in the world and ranks as the world's second most populous home of humans. It covers $6 \%$ of the earth and $20.4 \%$ of its total land area. With more than a billion people, it accounts for about $14.72 \%$ of global population and in many of its countries these are of the youthful age group - using Nigeria, the most populous nation in the continent as a random example, $70 \%$ of its population is under 35 years and this is an added advantage because young people are a powerful potential for any entity (UNFPA, 2011, 10).

Just as China is using other things to blend to its size and population to move forward, Africa can use its enormous natural potential and its multiple endowments which are at times difficult to quantify because of their abundance, to become a major force in international politics. With all it has which others highly need, the continent, aware or unaware, is actually in possession of what it takes to influence major international decisions as well as the comportment of aspiring states. No world power rises to the level of global leadership without a sustainable economic base. Throughout the different periods in contemporary history, the place of the continent's resources in birthing a new world power remains sure and incontestable and just as others understood this and came knocking at its door before, during and after the industrial revolution, so probably have the Chinese come. In fact, it should be noted that certain trends have remained close to the rise of powers in different historical periods. Some of them change but others remain static, keeping to the same logic. As Henry Kissinger observes:

Almost as if according to some natural law, in every century there seems to emerge a country with the power, the will and the intellectual and moral impetus to shape the entire international system in accordance with its own values. In the Seventeenth century, France under Cardinal Richelieu introduced the modern approach to international relations, based on the nation-state and motivated by national interest as its ultimate purpose. In the eighteenth century, Great Britain elaborated the concept of the balance of power which dominated European diplomacy for the next 200 years. In the nineteenth century, Metternich's Austria reconstructed the Concert of Europe and Bismarck's Germany dismantled it, reshaping European diplomacy into a cold-blooded game of power politics.

In the Twentieth century, no power has influenced international relations as decisively and at the same time as ambivalently as the United States (Kissinger, 1994, 17).

Looking into this, the arrival or perhaps, emergence of China in the 21 st century is neither too surprising nor a coincidence which just occurred suddenly, taking everyone off guard. Rather, it is a thing that has followed familiar trends which have existed for centuries and seems to be developing into an established formula as far as the birth of a new strongman to steer the affairs of the world is concerned. For a long time in history, Africa has always been part of the equation of making a new world power and presently in this new century, China is not only firmly clinging on the continent but is prudent to ensure not only that they are in good terms but wants to win it to its side. The Asian giant seems to currently be on the right track and is rising and thriving in the midst of a serious global crisis which has seen many go down despite 
deploying much of their finest brains and trying quite hard to stay afloat. This has remained a puzzle and has generated much incomprehension as many cannot understand why the economic situation continues remaining so messy for many years despite the enormous expert efforts deployed to have things under control. But as the Bible book of Ecclesiastes 9:11 teaches, 'the race is not to the swift, nor the battle to the strong, neither yet bread to the wise, nor yet riches to men of understanding, nor yet favour to men of skill; but time and chance happens to them all' (The Bible, 2007, 700). Fascinating indeed! According to Rotberg, Africa and China desperately need one another because of the role each has to play in fulfilling the dreams of the other - Africa, development and China, world leadership through consistent growth (Rotberg, 2008 , 1). China does not, it must be made clear, have any monopoly of knowledge of the development needed in Africa, others do as well but what is partly making the difference is the current strategies being used and possibly, the time and chance factor.

This is even more real in the current paradigm of postmodernism where development can take many forms provided it suits the context of the concerned, and must not obligatorily be the unique, universally prescribed one characterised by standards which everyone strove to attain but never succeeded because the standards remained tantalising, unattainable, and just too alien to fit in certain settings.

\section{2. Using postmodernism to explain the hostilities against China in Africa}

China has been at the receiving end of intense criticisms since its current connection with Africa got to an elevated level. Inasmuch as some of these criticisms might be legitimate, we shall briefly attempt to explain them in the light of change and postmodernism. In fact, change, or any upset of established norms, never occurs without facing either resistance from those who benefited from the previous order or arousing fear and uncertainty from those who are unsure of what the new order might bring. When the modern era, for instance, burst into the scene, taking over from the pre-modern, many resisted it especially workers and the feudal lords whose jobs were taken over by machines. Similarly, during the age of learning for instance, there was a massive influx of intellectual ideas which threatened previously held modes of conservative thinking and living patterns, eroding the privileges of those who benefited from the old order but not without facing intense resistance from them too (Tandon, 2009, 2). But at times, it is worth daring to think differently and challenging one's own believes systems to accommodate new realities which, in many cases, have tended not to be as injurious as initially feared.

In like manner, when the discourse of postmodernism began, it was resisted by modern values and till date, continues facing challenges of acceptance and some even counsel that it should be taken with much caution. Inasmuch as it might be quite deconstructive, it is at the same time very constructive and worth permitting to live. As Best and Kellner put it "Dramatic changes in society and culture are often experienced as an intense crisis for those attached to established ways of life and modes of thought. The breaking up of once stable social orders and patterns of thought frequently evoke a wide spread sense of social incoherence, fragmentation, chaos and disorder. The response is often despair and pessimism, panic and hyperbolic discourse and desperate searches for solution to the apparent crisis" (Best and Kellner, 1991, 8).

To a very great extent, this is reflected in the way certain powers, which are used to being in charge, have reacted to China's sudden rise and threats to overtake them. Going by the virulence and ferociousness of some of the voices directed against the issue of the rising power's ways and activities, it might seem as if China is not doing anything right. Looking too at the defence China puts up for itself and the way it is carefully forging on with its agenda and being so careful of not having anyone thwart its plans, it is evident that China, like its rivals, is 
influenced by a mindset of classical realism. For a quick reminder, classical realism is a state level theory which argues that all states seek power and try to be in an advantageous position to others. In this way, they work to increase their power and reduce that of others especially that of those considered as enemies. Humans are seen here to be selfish, dangerous and aggressive and so it is believed that the states they govern will resemble them, everything being equal. Consequently, to have power in one's enemy's hands and not in one's own hands is threatening, dangerous and unwise. Hence, it is prudent to be the one who wields power, not the other. If things cannot be this way, there should be balance of power. Therefore, though there are certainly legitimate complaints against China's comportment, this is obviously a strong underlying reason why the others are much alarmed and concerned about China's rapid rise which risk paving the way for it to assume the mantle of leadership and it is equally why China is so defensive of its every action, questioning why with all it is capable of, it should play second fiddle and not work to make the pendulum of power swing to its side in 'favourable' times such as now.

As highlighted earlier, breaking up with the status quo is always a tough moment indeed and a truth too bitter and challenging to accommodate. Just as it was the turn of others and they effectively took over, things are currently working for China but it still needs time to confirm whether it is truly its time or just a moment of difficult-to-explain uncertainties. Just as others came to Africa and got what it takes to power the engine of the economy to lead the world, so, perhaps, might have China come to what might be adequately referred to as 'the king maker' to get the unction to function as a leader and get possession of that thing which enables an aspirant to firmly position itself in the cockpit of world affairs.

\section{CONCLUSION}

The world is evolving and so are the prevailing systems that mankind has known. From the era of city states in the Athenian Democratic Model, the world has gone through a succession of systems which come and go. In the 20th century, states witnessed the advent of a form of totalitarianism during which world class dictators and the two world wars provided instances for humankind to taste and discover the futility and emptiness of the diplomacy of brute force. In fact, during this period, in many instances, might was right and the ideology of an absolute truth, which is a major feature of modernism, was so prevalent that people believed strongly in their believes and held firm to them even if such believes led to the direction of injuring and hurting others. It was the period when, for instance, slogans like 'Mussolini is always right,' referring to the splendour and absoluteness of the Italian strongman and 'The Empire on Which the Sun Never Sets,' referring to the vastness and seemingly unlimited greatness of notably British colonial power, were common and they made a lot of sense, at least from the way things were at the time. It might have been concluded that that was the absolute truth.

Postmodernism has played a significant role in modifying and in many cases, deconstructing much of certain believe patterns. Things have changed and are still changing. Not only has the postmodern mindset proven that there is not only one way of looking at a thing, it has also successfully provided evidence of the limitations of the human scope of thinking such that for anyone to say nowadays that he is always right, will not only attract challenges but will sound absurd because in the current dispensation of postmodern thought, right and wrong are relative and mean different things to different people and can change. 
Similarly, states and even individuals have realised how naïve and inaccurate it is to think in one absolute direction which they will use every available force to defend.

Soft power and a multiplicity of hybrid approaches are now used because states are increasingly realising that in this global information and hi-tech age, there are multiple ways of getting to one's objectives; and the success of a state in this era does not depend solely on the size of its army or the victories it records but is connected to a lot of variables including whose habit is appealing and who respects and is fair towards others.

China seems to have understood this quite well and is busy using its soft power all over Africa, putting on a saint-like comportment, giving interest-free loans, and supporting Africanled efforts to sustainability. Many African governments are enthusiastic about it - with strong reasons of course, especially those composed of individuals who do not like to be screened and constantly compelled to give accounts of their transactions. While it is scholarly ethical to scrutinise such relations and call them what one feels, it is challenging to just give them a conclusive name because as this chapter has demonstrated, judgment is always relative and context-based and to put a full stop and insist that that is where it ends can be worrisome indeed. There is a way these relations can be described which will not only loss touch with the reality on the ground but will be insinuating that one of the parties does not know what it is doing and is merely being fooled by the other. Though this is a possibility that cannot be ruled out, it is expedient to adequately understand the nitty-gritty of this new romance Africa is having with this seemingly new suitor and have a full grasp of the dynamics of such connections to increase one's probability of judging justly. Let us, therefore, have our eyes fixed on this new relationship and see what becomes of it because in our postmodern context, everything remains open and anything is possible.

\section{References}

[1] Best, Steven and Douglas Kellner, Postmodern Theory: Critical Interrogations, New York, the Guilford Press, 1991.

[2] Bezlova, Antoaneta, "China's Soft Power Diplomacy in Africa", Asia Times Online, June 23, (1-2) 2006.

[3] Brautugam, Deborah, The Dragon's Gift: the Real Story of China in Africa, Oxford, Oxford University Press, 2009.

[4] Busia, Kofi A., The Position of the Chief in the Modern Political System of Ashanti, London, Frank Cass, 1968.

[5] Esteva, Gustavo, "Development", in Wolfgang, Dietrich et al. (eds.), Schlüsseltexte der Friedensforschung: Die Kommende Demokratie, Berlin, LIT, 2006.

[6] Gaye, Adama, China-Africa: the Dragon and the Ostrich, Paris, l'Harmattan, 2006.

[7] Gomes, Alberto, “Alter-Native 'Development': Indigenous forms of Social Ecology”, (unpublished), La Trobe University, 2012.

[8] Kissinger, Henry, Diplomacy, New York, Simon and Schuster Paperbacks, 1994.

[9] Kurlantzick, Joshua, Charm Offensive: How China's Soft Power is Transforming the World, New York, Yale University, 2007. 
[10] Kurlantzick, Joshua et al., "China's Africa Strategy: A New Approach to Development and Diplomacy?" Carnegie Endowment for International Peace, December 12, (1-2) 2006.

[11] Martínez-Alier et al., "Sustainable de-growth. Mapping the Context, Criticisms and Future Prospects of an Emergent Paradigm" in Ecological Economics no. 69 (2010) 1741-1747.

[12] Michel, Serge and Michel Beuret, China Safari: on the Trail of Beijing's Expansion in Africa, New York, Nation Books, 2009.

[13] Mingjiang, Li, “Soft Power: Nurture not Nature," in Mingjiang, Li (ed.): Soft Power: China's Emerging Strategy in International Politics, Maryland, Lexington Books, 2009.

[15] Nye, Joseph Jr., Soft Power: the Means to Success in World Politics, New York, Public Affairs Publication, 2004.

[16] Rotberg, Robert ed., China into Africa: Trade, Aid and Influence, Washington, D.C., Brooking Institution Press, 2008.

[17] Rourke, John, International Politics on the World Stage, 3rd edition, Connecticut, Dushkin Publishing Group, 1991.

[18] Sautman, Barry, "Friends and Interests: China's Distinctive Links with Africa", Working Paper no. 12, Hong Kong, Centre on China's Transnational Relation, 2006.

[19] Tandon, Yash, Development and Globalization: Daring to Think Differently, Cape Town, Pambazuka Press, 2009.

[20] The Bible, The Holy Bible, New King James Version 2000, Chicago, The Bible League, 2007.

[21] UNFPA, UNFPA State of World Population 2011: People and Possibilities in a World of 7 Billion, UNFPA, 2011.

[22] Zartman, William and Jeffery Rubin, "The Study of Power and the Practice of Negotiation", in Zartman, William and Jeffery Rubin (eds.), Power and Negotiation, Michigan, University of Michigan Press, 2000. 